\title{
'Talisman' Northern Highbush Blueberry: A Productive Late-midseason Cultivar
}

\author{
Mark K. Ehlenfeldt \\ U.S. Department of Agriculture, Agricultural Research Service, Philip E. \\ Mariucci Center for Blueberry and Cranberry Research and Extension \\ (Rutgers University), 125A Lake Oswego Road, Chatsworth, NJ 08019
}

Additional index words. Vaccinium corymbosum, public domain, mechanical harvest

'Talisman' is a new northern highbush blueberry (Vaccinium corymbosum) cultivar developed by the U.S. Department of Agriculture, Agricultural Research Service (USDA-ARS). The new cultivar has several advantageous attributes for blueberry growers in the northtemperate United States: reliable productivity, excellent yields, late-midseason ripening, medium-large fruit, uniform size, light-blue fruit color, and easy fruit removal force making it suitable for mechanical harvest. 'Talisman' is released as a public domain cultivar.

\section{Origin and Description}

'Talisman' originated from a cross of 'Magnolia' $\times$ 'Elizabeth' (Fig. 1), and it was tested as ARS 05-171. 'Magnolia' is a southern highbush cultivar (USDA, 1994) and derives from the cross Fla 78-15 × Fla 72-5. 'Elizabeth' is a northern highbush cultivar released from New Jersey (New Jersey Blueberry Council, 1966) and derives from the cross ('Katherine' $x$ 'Jersey') $\times$ 'Scammell'. Based upon this parentage, 'Talisman' is calculated to be $\approx 87 \% \mathrm{~V}$. corymbosum $\mathrm{L}$. and $\approx 13 \%$ other species, primarily $V$. darrowii Camp. (5\%) and V. virgatum Ait. (syn. $V$. ashei Reade) $(\approx 4 \%)$, with small amounts of other species (Brevis et al., 2008; Ehlenfeldt, personal communication).

The cross for 'Talisman' was made in 2000 by M.K. Ehlenfeldt at the Philip E. Marucci Center for Blueberry and Cranberry Research and Extension (Rutgers University), Chatsworth, NJ. 'Talisman' was selected in 2005 at the same location, and was subsequently evaluated in commercial-farm test-plots in Hammonton, NJ by M.K. Ehlenfeldt and R.B. Martin Jr. from 2013 to 2019.

\section{Fruit Quality Comparisons}

'Talisman' is a late-midseason/lateseason cultivar with concentrated ripening

Received for publication 17 July 2020. Accepted for publication 16 Oct. 2020.

Published online 25 November 2020.

M.K.E. is the corresponding author. E-mail: mark. ehlenfeldt@usda.gov.

This is an open access article distributed under the CC BY-NC-ND license (https://creativecommons. org/licenses/by-nc-nd/4.0/). suited for production by commercial growers. For comparison purposes, 'Talisman' was initially compared with 'Duke', a commercial early-season quality standard (Draper et al., 1987). Numerical ratings of 'Talisman' vs. 'Duke' in 2010 to 2015 showed 'Talisman' equal or better than 'Duke' in most fruit quality characters except for firmness. For this trait, 'Duke' was rated as firmer (7.2 for 'Talisman' vs. 7.7 for 'Duke' on a 1-9 scale) (Table 1). It is worth noting that both cultivars are mild flavored (7.1 for 'Talisman'; 6.7 for 'Duke'). Productivity of both cultivars was very good $(>7 ; 1-$ 9 scale).

Similar numerical ratings of 'Talisman' vs. two commonly grown late-ripening cultivars, Liberty and Elliott, showed 'Talisman' to ripen synchronously with 'Liberty' and to crop more heavily, but to exhibit lower firmness and flavor ratings than 'Liberty' (Table 2). 'Talisman' was superior to 'Elliott' in rated characteristics, but 'Elliott' was a better choice if a truly late-ripening cultivar was desired.

In detailed evaluations compared with 'Duke', the early-season quality standard, 'Talisman' demonstrated excellent yields, although slightly less than 'Duke' (5.8 $\mathrm{kg} /$ bush vs. $6.2 \mathrm{~kg} / \mathrm{bush}$ ) (Table 3). 'Talisman' exhibited a larger berry size $(2.0 \mathrm{~g} \pm 0.5)$, higher firmness $(194 \mathrm{~g} / \mathrm{mm} \mathrm{dfl} \pm 22)$, higher soluble solids $\left(10.7{ }^{\circ}\right.$ Brix \pm 1.4$)$, and higher titratable acidity $(0.94 \%$ citric acid eq. \pm 0.43$)$ than 'Duke', but the values for all of these traits were generally comparable. Although 'Talisman' had higher firmness values than 'Duke' in the commercial farm evaluations, 'Duke' retains its firmness and softens less after harvest than 'Talisman' and thus is superior in long-term storage quality. Both 'Talisman' and 'Duke' are considered mild flavored, and they are considerably less acidic than midseason cultivars such as Bluecrop or mid-late cultivars such as Liberty. Due to its mild flavor, 'Talisman' should benefit, when feasible, from water limitation before harvest to concentrate both acids and sugars. Similarly, wine-grape growers have recognized that limiting potassium fertilization can improve acidity levels in grapes (Mpelasoka et al., 2003); similar potassium manipulation might benefit cultivars such as Duke and Talisman.

\section{Plant Characteristics}

'Talisman' is suitable for production in areas where highbush blueberries are typically grown. Its flowering time is very late (similar to 'Elliott'), and thus is likely to avoid spring frost problems. Cold hardiness testing using a detached-shoot freeze-thaw assay (Rowland et al., 2005) has shown it to have cold hardiness comparable to typical northern highbush $\left(\mathrm{LT}_{50}=-27.0{ }^{\circ} \mathrm{C}\right.$ vs. $\mathrm{LT}_{50}=-25.6{ }^{\circ} \mathrm{C}$ for 'Duke', 2012-14, data not shown).

Flowers of 'Talisman' are elongate and roughly urceolate-cylindrical, with delicate pink highlights near the corolla base (Fig. 2). Pollination tests have shown it to be highly self-fruitful $(1.9 \mathrm{~g} /$ berry selfed, $2.1 \mathrm{~g} /$ berry outcrossed), suggesting it will be suitable for planting in solid blocks in the field. Fruit

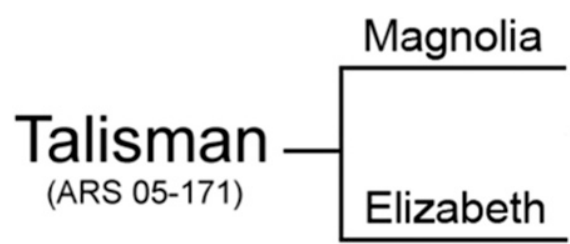

Fig. 1. Pedigree of 'Talisman' northern highbush blueberry.

Table 1. Average numerical ratings ( $\pm \mathrm{SD}$ ) of 'Talisman' and 'Duke' (an early ripening, standard commercial cultivar) at Chatsworth and Hammonton, NJ, 2010-15.

\begin{tabular}{lcccccc}
\hline Cultivar & Size $^{\mathrm{z}}$ & Scar & Color & Firmness & Flavor & Productivity \\
\hline Talisman & $7.4 \pm 0.5$ & $7.5 \pm 0.4$ & $7.7 \pm 0.3$ & $7.2 \pm 0.2$ & $7.1 \pm 0.5$ & $7.4 \pm 1.2$ \\
Duke & $7.2 \pm 0.4$ & $7.4 \pm 0.5$ & $7.4 \pm 0.5$ & $7.7 \pm 0.4$ & $6.7 \pm 0.7$ & $7.8 \pm 0.8$ \\
\hline
\end{tabular}

${ }^{\mathrm{z}}$ Characteristics were rated on a 1 to 9 scale, where $1=$ poorest and $9=$ best. Ratings taken at $\approx 40 \%$ ripeness.

Table 2. Ratings of 'Talisman' vs. the later season ripening varieties, 'Liberty' and 'Elliott', at the P.E. Marucci Center, Chatsworth, NJ, 18 July 2018.

\begin{tabular}{lccccccc}
\hline Cultivar & Size $^{\mathrm{z}}$ & Scar & Color & Firmness & Flavor & Productivity & Ripeness (\%) \\
\hline Talisman & 8 & 8 & 8 & 7.5 & 7.5 & 8 & 85 \\
Liberty & 8 & 8 & 8 & 8 & 8.5 & 7 & 85 \\
Elliott & 7.5 & 7 & 8 & 7.5 & 7 & 7.5 & 50 \\
\hline
\end{tabular}

${ }^{\mathrm{z}}$ Characteristics were rated on a 1 to 9 scale, where $1=$ poorest and $9=$ best. 
Table 3. Multi-year ratings ( $\pm \mathrm{SD}$ ) of 'Talisman' vs. 'Duke' (early season quality standard).

\begin{tabular}{llcccccc}
\hline Selection & Yield $^{\mathrm{z}}(\mathrm{kg})$ & ${\text { Berry wt }(\mathrm{g})^{\mathrm{y}}}$ & ${\text { Firmness }(\mathrm{g} / \mathrm{mm} \mathrm{dfl})^{\mathrm{x}}}$ & ${\text { Color }(\mathrm{L} .)^{\mathrm{w}}}$ & Sol. solids (Brix) $^{\mathrm{v}}$ & ${\text { Tit. acidity }\left(\% \text { cit. acid equivalents) }^{\mathrm{u}}\right.}^{\text {50\% ripe date }}$ \\
\hline Talisman & $5.8 \pm 1.9$ & $2.0 \pm 0.5$ & $194 \pm 22$ & $28.1 \pm 3.8$ & $10.7 \pm 3.8$ & $0.94 \pm 0.43$ \\
Duke & $6.2 \pm 2.5^{\mathrm{s}}$ & $1.7 \pm 0.3$ & $181 \pm 11$ & $29.0 \pm 3.4$ & $9.8 \pm 0.8$ & $0.60 \pm 0.16$ & $18 \mathrm{July} \pm 5$ \\
\hline
\end{tabular}

${ }^{\mathrm{z}}$ Values were based on the yields of the middle three bushes of a five-plant test plot.

${ }^{y}$ Individual year berry weights were based upon the average of 30 randomly selected berries from yield pickings in 2013-18. Summary values were averaged across years. ${ }^{\mathrm{x}}$ Firmness values expressed as grams of force per mm of deflection in 2013-18. Firmness readings were based upon the average of 50 berries evaluated with a Firmtech 2 tester (Stillwater, OK). Summary values were averaged across harvests and years.

${ }^{\mathrm{w}}$ Color in the $\mathrm{L} * \mathrm{a} * \mathrm{~b} *$ color coordinate system as defined by the Commission Internationale l'Eclairage (CIE). L coordinate indicates lightness; higher numbers indicate a lighter color. Color readings were done on bulk samples from yield harvests in 2013-15 and 2019.

${ }^{\mathrm{v}}$ Soluble solids were estimated in 2013-18 using juice prepped for titratable acidity and represent the juice from a blended 237-mL (1-cup) fruit sample.

uTitrable acidity was evaluated in 2013-18 on a sample taken from a blended 237-mL (1-cup) fruit sample.

${ }^{\mathrm{t}}$ The $50 \%$ ripeness dates were determined in 2013-19 based on interpolation of percent yield calculated for each weekly harvest.

s'Talisman' yield values are from 2013 to 2019 . 'Duke' yield values are from 2013 to 2015 and 2019. 'Duke' standards were damaged in 2016, and were judged atypical in 2016-18.

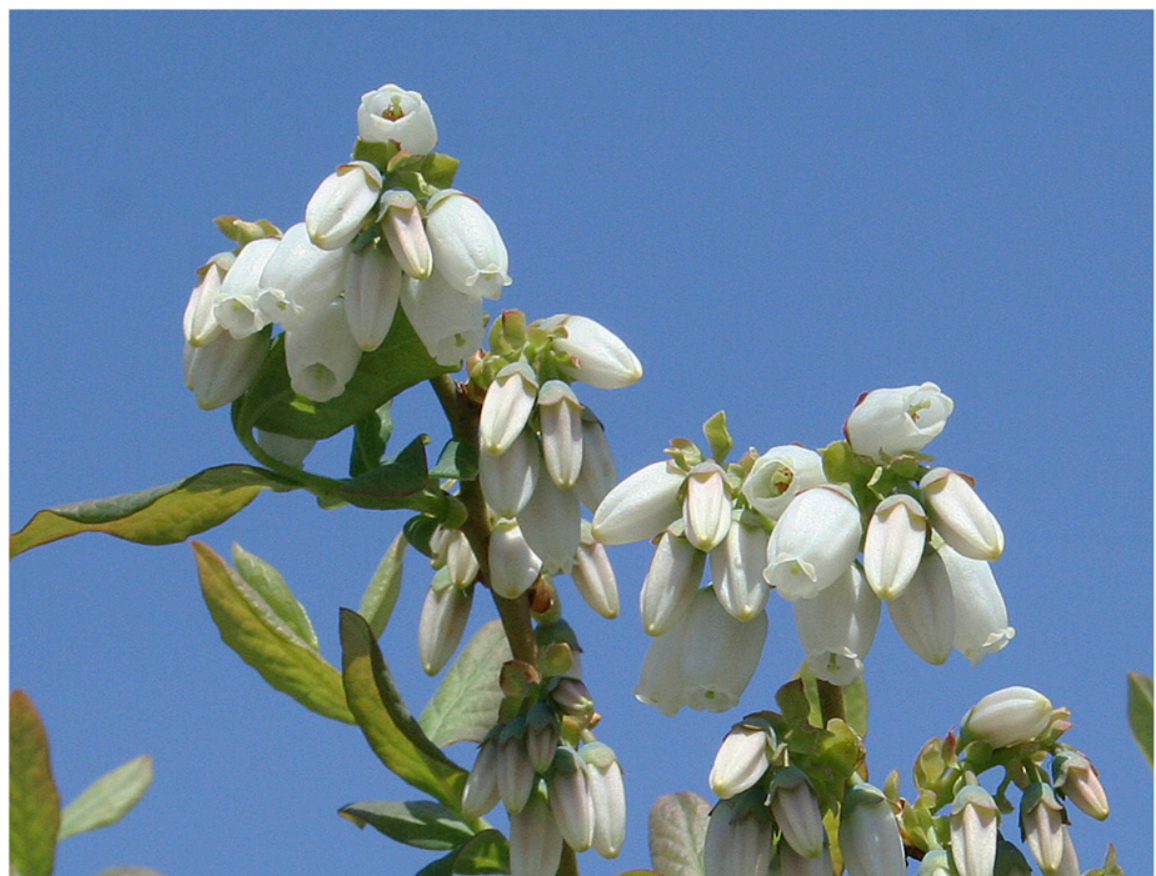

Fig. 2. Flowers of 'Talisman' northern highbush blueberry.

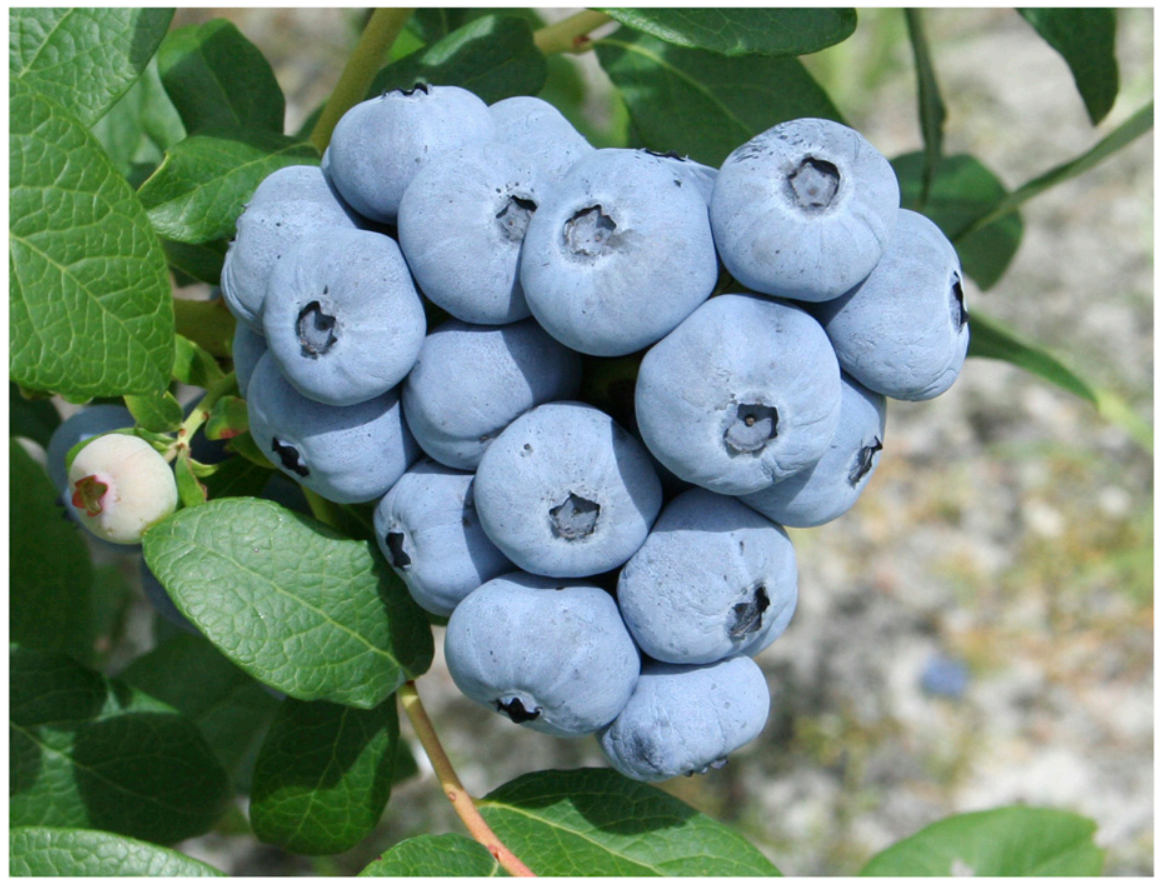

Fig. 3. Fully ripe fruit of 'Talisman' northern highbush blueberry. develops uniformly, and the plant produces compact, well-exposed clusters of uniformsized fruit that ripen in a concentrated period in late-midseason ('Liberty'/'Jersey' season) (Fig. 3). Subjective evaluations show 'Talisman' has an easy fruit removal force, potentially suited to mechanical harvesting.

Plants of 'Talisman' are vigorous and robust, with a rounded growth habit and a narrow base (Fig. 4). Plants tend to have stocky growth and may need assertive management at a young age to induce sufficient branching to form a balanced bush, and to avoid producing a monopodial plant. 'Talisman' has demonstrated good field resistance to both phases of the fungal disease mummy berry, Monilinia vaccinii-corymbosi (Scherm and Hildebrand, 2017) (blight rated as equal to 1 on a 1-5 scale, comparable to 'Bluecrop' and 'Legacy'; mummy berry fruit infection is equal to low).

\section{Availability}

'Talisman' is released as a public domain cultivar by the USDA-ARS, and as such it may be freely propagated and grown without licensing restrictions. It is unconditionally released with no warranty given regarding its performance or adaptation under specific environmental or cultural conditions. The U.S. Department of Agriculture, Agricultural Research Service does not have plants for distribution, but can provide information on sources of propagules for interested nurseries, breeders, or researchers. Requests for information should be addressed to Dr. Mark Ehlenfeldt, Philip E. Marucci Center for Blueberry and Cranberry Research and Extension, 125A Lake Oswego Road, Chatsworth, NJ 08019 or Mark. Ehlenfeldt@usda.gov. Genetic material of 'Talisman' will be deposited in the National Plant Germplasm System, where it will be available for research purposes, including development and commercialization of new cultivars. It is requested that appropriate recognition be made if this germplasm contributes to the development of a new breeding line or cultivar.

\section{Literature Cited}

Brevis, P.A., N.V. Bassil, J.R. Ballington, and J.F. Hancock. 2008. Impact of wide hybridization on highbush blueberry breeding. J. Amer. Soc. Hort. Sci. 133:427-437, doi: 10.21273/JASHS 133.3.42.

HortScience Vol. 56(1) JANUARy 2021 


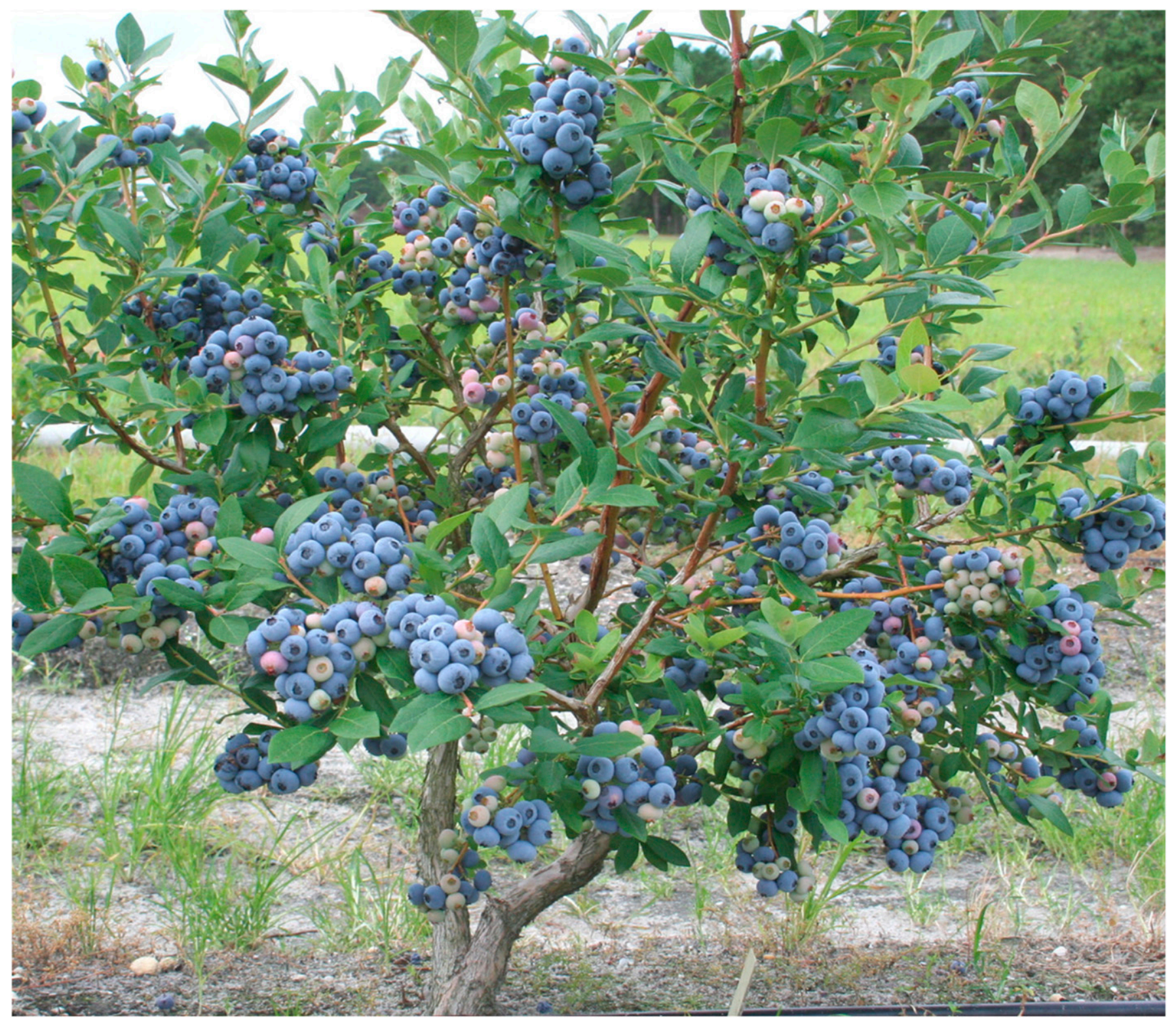

Fig. 4. A five-year-old bush of 'Talisman' northern highbush blueberry in fruit.

Draper, A., G. Galletta, G. Jelenkovic, and N. Vorsa. 1987. 'Duke' highbush blueberry. HortScience 22:320.

Mpelasoka, B.S., D.P. Schachtman, M.T. Treeby, and M.R. Thomas. 2003. A review of potassium nutrition in grapevines with special emphasis on berry accumulation. Aust. J. Grape Wine Res. 9:154-168, doi: 10.1111/j.17550238.2003.tb00265.x.
New Jersey Blueberry Council. 1966. The Elizabeth blueberry. NJ.

Rowland, L.J., E.L. Ogden, M.K. Ehlenfeldt, and B. Vinyard. 2005. Cold hardiness, deacclimation kinetics, and bud development among 12 diverse blueberry (Vaccinium spp.) genotypes under field conditions. J. Amer. Soc. Hort. Sci. 130:508-514, doi: 10.21273/JASHS.130.4.5.

Scherm, H. and P.D. Hildebrand. 2017. Mummy berry, p. 30-32. In: J.J. Polashock, F.L. Caruso,
A.L. Averill, and A.C. Schilder (eds.). Compendium of blueberry, cranberry, and lingonberry diseases and pests. 2nd ed. APS Press, St. Paul, MN.

U.S. Department of Agriculture. 1994. Notice to nurserymen of the naming and release for propagation of Pearl River, Magnolia, and Jubilee, three new southern highbush blueberry cultivars. Washington, D.C. 